\title{
Lake trophic states shape microbial community structure in sediments
}

\section{Other Conference Item}

\section{Author(s):}

Han, Xingguo; Schubert, Carsten; Fiskal, Annika; Dubois, Nathalie; Lever, Mark (1)

Publication date:

2020-05

Permanent link:

https://doi.org/10.3929/ethz-b-000455385

Rights / license:

Creative Commons Attribution 4.0 International

Originally published in:

EGUsphere, https://doi.org/10.5194/egusphere-egu2020-9772 
EGU2020-9772

https://doi.org/10.5194/egusphere-egu2020-9772

EGU General Assembly 2020

(c) Author(s) 2020. This work is distributed under

the Creative Commons Attribution 4.0 License.

\title{
Lake trophic states shape microbial community structure in sediments
}

\author{
Xingguo Han ${ }^{1}$, Carsten Schubert ${ }^{2}$, Annika Fiskal ${ }^{1}$, Nathalie Dubois ${ }^{3,4}$, and Mark Lever ${ }^{1}$ \\ ${ }^{1}$ Institute of Biogeochemistry and Pollutant Dynamics, Swiss Federal Institute of Technology, Zurich (ETH Zurich), Zurich, \\ Switzerland (xingguo.han@usys.ethz.ch) \\ ${ }^{2}$ Department of Surface Waters - Research and Management, Swiss Federal Institute of Aquatic Science and Technology \\ (EAWAG), Kastanienbaum, Switzerland(carsten.schubert@eawah.ch) \\ ${ }^{3}$ Department of Earth Sciences, Swiss Federal Institute of Technology, Zurich (ETH Zurich), Zurich, Switzerland \\ (nathalie.dubois@eawag.ch) \\ ${ }^{4}$ Department of Surface Waters - Research and Management, Swiss Federal Institute of Aquatic Science and \\ Technology(EAWAG), Dübendorf, Switzerland (nathalie.dubois@eawag.ch)
}

Lake sediments are globally important carbon sinks, and play a critical role in the global carbon cycle. Although the fate of organic carbon in lake sediments depends mostly on sedimentary microorganisms, the environmental controls on the microbial community structure in lake sediments are still poorly understood.

Here we investigate the relationships of lake trophic state, sediment redox chemistry, sediment organic matter $(\mathrm{OM})$ sources and microbial community structure in sediment records across five lakes with different eutrophication histories and trophic states in central Switzerland. Our results show that, across all five lakes, bacterial and archaeal communities based on 16S rRNA gene sequencing analyses show similar sediment depth-dependent zonations at the phylum- and classlevel, which appears to be primarily driven by vertical distributions of electron acceptors and secondarily by differences in the contributions of aquatic and terrestrial OM revealed by biomarkers. Yet, there are clear differences in microbial communities between lakes, most notably the higher abundances of putatively aerobic nitrifying Bacteria (Nitrospirae) and Archaea (Marine Group I, Thaumarchaeota) in anoxic sediments of oligotrophic Lake Lucerne. Furthermore, at the level of Zero-radius Operational Taxonomic Unit (ZOTU), eutrophication-related trends are more pronounced, in which microbial communities in the sediments of eutrophic lakes are more similar and share more ZOTUs with each other than with the oligotrophic lake. Notably, deep sediment layers of presently eutrophic lakes that were deposited prior to the era of eutrophication show high similarities in bacterial communities to equivalent depths in the oligotrophic lake. By contrast, archaeal communities are clearly differentiated according to trophic state only in recently deposited sediment layers, and independent of trophic state converge toward high similarities over time.

Our study indicates a significant role of trophic status in driving lacustrine sediment microbial communities and reveals fundamental differences in the temporal responses of bacterial and 
archaeal communities to anthropogenic eutrophication. 